\title{
The Process of Domestication in Triatominae
}

\author{
CJ Schofield ${ }^{+}$, Lileia Diotaiuti*, JP Dujardin** \\ Department of Infectious and Tropical Diseases, LSHTM, London WC1 E7HT, UK *Centro de Pesquisas Rene \\ Rachou-Fiocruz, Av. Augusto de Lima 1715, Belo Horizonte, MG Brasil **ORSTOM/IBBA, Casilla Postal \\ 9214, La Paz, Bolivia
}

Key words: Triatominae - Chagas disease - population genetics - domestication - dispersal

The Triatominae represent a subfamily of the Reduviidae defined on the basis of their bloodsucking habit and associated characteristics. At present, 128 species are formally recognised, grouped into 17 genera in 5 tribes. The majority are silvatic, associated with a wide variety of vertebrate hosts - particularly nest-building mammals and birds. Others occupy silvatic and peridomestic habitats such as chicken coops and goat corrals, and a few have completed the transition to domestic habitats where they may become important as domestic vectors of human Chagas disease.

The most highly domesticated species, such as Triatoma infestans in Southern Cone countries, and Rhodnius prolixus in parts of the Andean Pact and Central America, are now being progressively controlled through regional and national initiatives designed to eliminate domestic populations by residual insecticide spraying. In recent years however, there have been increasing reports of other species establishing domestic colonies, and some, such as $T$. dimidiata, have even invaded urban and periurban residences. In many cases, the new infestations involve little-known species previously considered to be exclusively silvatic in habit, such as Panstrongylus rufotuberculatus, Rhodnius stali, and Eratyrus mucronatus in Bolivia (Noireau et al. 1995, Dujardin et al. 1998a), and P.geniculatus in the Amazon region (Valente et al. 1998). It seems clear therefore, that the process of domestication in Triatominae is not only a historical event, but may be a generalised current trend within the subfamily (cf. Diotaiuti 1997). Here we present a general description of the evolutionary process, as a basis for discussion of the possible mechanisms involved and their likely consequences.

\footnotetext{
This work has benefited from international collaboration through the ECLAT network.

${ }^{+}$Corresponding author. Fax: +33-4-50-20.6377. E-mail: cj.schofield@wanadoo.fr

Received 9 June 1999

Accepted 9 August 1999
}

\section{EVOLUTION OF HAEMATOPHAGY}

The Triatominae are believed to have evolved from various reduviid lineages, adapting first as nest-dwelling predators, through phases of facultative blood-sucking towards obligate haematophagy in association with a range of vertebrate hosts and their habitats. This evolutionary route appears to have been followed several times in the Americas to give rise to the polyphyletic genus Triatoma and several smaller genera, and also to have proceeded at least once in the Indian subcontinent to give the genus Linshcosteus (Gorla et al. 1997). Anthocorid predators seem to have followed a similar evolutionary route in Africa and parts of Asia to give rise to the Cimicidae and Polyctenidae, and may have inhibited this evolutionary step in African reduviids by being earlier to occupy the available nidiferous ecotopes.

Evolution from predaceous to blood-sucking habits is associated with a series of morphological, behavioural and demographic changes associated with three key factors: (1) exploitation of verteberate blood as a food source, (2) adaptation to the host environment, and (3) progressive reliance on the host as a means for dispersal by passive carriage (Schofield \& Dolling 1993). Inevitably this can lead to convergence in relevant characters, so that the form of the evolved blood-sucker will include both its evolutionary background together with specific convergences associated with exploitation of the vertebrate hosts. The process involves specialisation and simplification reflected in genetic as well as phenotypic characteristics, and can be envisaged as a typical evolution of demographic strategy (sensu Rabinovich 1974) from $r$ strategists ('free-living' predators adapted to relatively unpredictable conditions of habitat and food supply) to $K$-strategists ('nest-dwelling' species exploiting a more stable habitat and food supply). In fact, this demographic transition seems to be one of the key factors driving the genetic changes seen in Triatominae (Schofield 1996).

The demographic consequence of habitat stability - especially stability of food supply and protection from climatic extremes - is that reproduc- 
tion becomes less impeded by food shortages and seasonal climatic changes. Reproduction proceeds through a greater part of the year, and populations can increase up to the limits imposed by available nutrition. At the limit however, when population density approaches the carrying capacity of the habitat, the nett rate of population increase declines inevitably towards unity $(R o=>1)$. At this point, the population neither increases nor decreases, meaning that each reproducing female is giving rise, on average, to just one reproducing daughter. But even at this point, the reproductive capacity of each female remains high, with each female capable of producing some 200 eggs. In other words, around $99 \%$ of offspring become unlikely to reach reproductive age. The genetic consequences involve constant selection for optimum genotype within that population, where 'optimum' can be envisaged as 'most efficient' in utilisation of the available resources. 'Most efficient', in turn, can be envisaged as 'not wasting energetic resources to produce genes or gene products that may not be used', so that both genetic and phenetic simplification can be predicted.

Evidence to support this idea comes from several sources. The sensory system of Triatominae, for example, in terms of the density of antennal sensilla, becomes progressively simplified in accordance with increasing habitat stability (Catalá 1997); bilateral symmetry becomes relaxed (Dujardin et al. unpublished), as does sexual dimorphism (Dujardin et al. 1999a,b), and a general reduction in body size may also be seen (Dujardin et al. 1997a,b, 1998b). At the chromosome level there is evidence for a decrease in total DNA per cell (Panzera et al. 1999), and expressed isoenzymes show a remarkable reduction in variability and polymorphism (Garcia et al. 1995, Frias \& Dujardin 1996, Dujardin et al. 1998a). Preliminary studies also indicate a progressive reduction in gene sequence variability (Garcia \& Powell, 1998, Garcia et al. 1998, Stothard et al. 1998, Lyman et al. 1999).

\section{THE PROCESS OF DOMESTICATION}

Domestication of Triatominae can be envisaged as an extension of the evolutionary route from predator to nest-dwelling bloodsucker, where the domestic habitat simply represents a particular type of vertebrate 'nest'. The process is one of specialisation and, since it seems to involve simplification of genetic as well as phenetic characters, we can assume the process to be irreversible. Generalist silvatic species may specialise to domestic habitats, but in so doing they would probably loose (by genetic simplification) the capacity to readapt to the less predictable silvatic habitats.
Genetic simplification during domestication occurs through two main processes - founder effects, followed by intraspecific competition as described above. Since only part of any silvatic genotypes may be successful in establishing durable domestic populations, it is inevitable that some genetic restriction will occur, since the founder of any new population can carry only a limited fraction of the available gene pool. In addition, if the newly founded population becomes isolated from its original silvatic foci (as can be expected if it is dispersed by the host over distances beyond its normal range), then a further loss of genetic variability can be expected (Figure) (Dujardin 1998). Genetic differences between silvatic and domestic populations seem to be good markers for incipient speciation, as has been demonstrated for $T$. infestans in Bolivia (Dujardin et al. 1997a,b, 1998a).

But although we are developing a reasonable description of the process, we are far from understanding the driving mechanism. In some cases there may be none, in the sense that domestic colonisation may simply be a chance occurrence. We can envisage that some individual bugs may be passively carried by an adventitious host to a new habitat, there to be accidentally dislodged to initiate a new colony. Indeed, passive carriage by the vertebrate host seems to explain most of the spread of domestic species such as T. infestans and

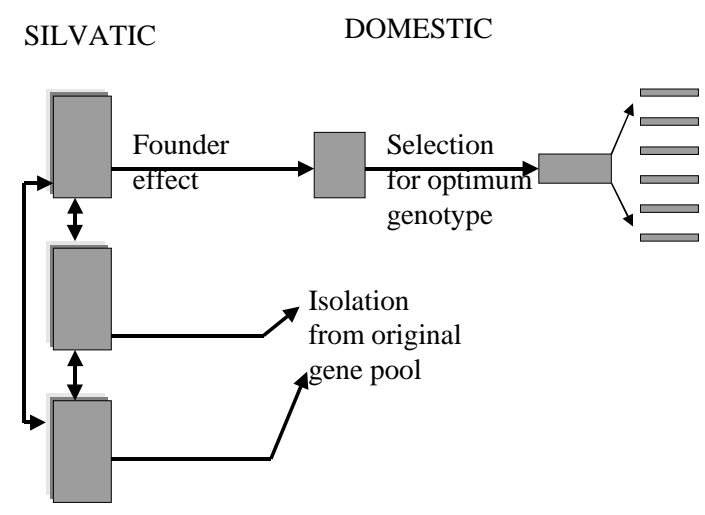

Schematic representation of the processes of genetic simplification in Triatominae during adaptation from silvatic to domestic habitats.

A subset of the silvatic gene pool forms the initial domestic colony, with consequent simplification by a founder effect. The domestic colony becomes progressively isolated from its silvatic origins, so that no further variability is introduced into the new population (except perhaps by occasional mutations). As the new domestic colony increases, there is intraspecific selection for optimum genotypes as the population density nears its carrying capacity. These processes may then be repeated as individuals are dispersed to neighbouring houses. 
$R$. prolixus (Dujardin et al. 1998a,b). It has also been invoked to explain the spread of wingless $T$. spinolai along the coast of Chile (Schofield et al. 1998) and may also explain the highly consistent associations with specific hosts seen in species such as T. delpontei, Cavernicola pilosa, and species of Psammolestes.

The alternative to passive dispersal by the vertebrate hosts involves active dispersal by flying adult bugs. All species of Triatominae - except for some T. spinolai - have wings in the adult stage. Some are known to be good fliers (eg. Schofield et al. 1992, Coura et al. 1994) although some members of the phyllosoma complex have such truncated wings that their capacity for active flight must be in some doubt. Laboratory studies and field observations of various triatomine species show that active flight is invariably associated with low nutritional status. Flying bugs are hungry, and this may indicate a key factor in the colonisation of new habitats. Ecological events such as deforestation may provoke mortality amongst the silvatic vertebrate hosts, leading to poor nutritional status for their associated triatomine bugs and prompting the adults to fly away in search of new habitats - such as houses - where new populations may be founded.

But this general idea leaves many questions unanswered. What, for example, are the main orientation signals for dispersing bugs? We know from numerous field observations that many triatomine species can be attracted at night to visible and UV light sources, but this does not apply to all species and cannot be the primitive mechanism leading to colonisation of new silvatic habitats. Are dispersing bugs attracted to general host odours, such as ammonia as has been proposed by Taneja and Guerin (1997). If so, why do we not see a greater miscellany of bug species attracted to particular habitats? In one study of the dispersive flight of $T$. infestans carried out on the salt flats of Argentina, the dispersal of bugs seemed to follow a random pattern -i.e. with no discernible orientation to a particular direction, except for a slight preponderance of bugs apparently attracted to a radiant heat source (Schofield et al. 1992). So is heat or other radiation an important signal for dispersing bugs?

Even the gender of dispersing bugs raises difficult questions. Clearly a mated female might initiate a colony in some new habitat, but dispersing males can colonise nothing. So what is the purpose of male dispersal? Is it a means to leave resources for their offspring - a sort of "pseudoapoptosis' - sacrificing the individual male so that his offspring can have greater access to the limited blood supply in the original habitat. If so, why are not all male bugs able to do this, given recent evidence that only a small proportion of individuals have the active form of the enzyme alpha-GPD crucial to flight initiation (Soares 1997).

We regret that this review perhaps raises more questions than answers, but understanding the mechanisms of domestication by Triatominae seems of crucial importance. It is now clear from experience in many countries that domestic populations of Triatominae can be eliminated by available methods, but the next phase in Chagas disease control must involve surveillance and monitoring of 'unusual' species that may - or may not - have the capacity to reinvade rural dwellings. We see this as one of the greatest research challenges in studies of Triatominae over the next decade.

\section{REFERENCES}

Catalá S 1997. Antennal sensilla of Triatominae (Hemiptera, Reduviidae): a comparative study over five genera. Intern J Insect Morphol and Embriol 26: 6773.

Coura JR, Barrett TV, Arboleda M 1994. Ataque de populações humanas por triatomineos silvestres no Amazonas: uma nova forma de transmissão da infecção chagásica? Rev Soc Bras Med Trop 27: 251-253.

Diotaiuti L 1997. Alterações ambientais e a colonização peridomiciliar pelo Triatoma sordida no Estado de Minas Gerais, Brasil. Acta Toxicol Argentina 5: 1562.

Dujardin JP 1998. Population genetics and the natural history of domestication in Triatominae. Mem Inst Oswaldo Cruz 93 (Suppl. II): 34-36.

Dujardin JP, Bermudez H, Casini C, Schofield CJ, Tibayrenc M 1997a. Metric differences between silvatic and domestic Triatoma infestans (Heteroptera: Reduviidae) in Bolivia. J Med Entomol 34: 544-551.

Dujardin JP, Bermudez H, Schofield CJ 1997b. The use of morphometrics in entomological surveillance of sylvatic foci of Triatoma infestans in Bolivia. Acta Tropica 66: 145-153.

Dujardin JP, Schofield CJ, Tibayrenc M 1998a. Population structure of Andean Triatoma infestans: allozyme frequencies and their epidemiological relevance. Med Vet Entomol 12: 20-29.

Dujardin JP, Munoz M, Chavez T, Ponce C, Moreno J, Schofield CJ 1998b. The origin of Rhodnius prolixus in Central America. Med Vet Entomol 12: 113-115.

Dujardin JP, Steindel M, Chavez T, Machane M, Schofield CJ 1999a. Changes in the sexual dimorphism of Triatominae in the transition from natural to artificial habitats. Mem Inst Oswaldo Cruz (in press).

Dujardin JP, Chavez T, Machane M, Solis S 1999b. Size, shape and genetics. Sexual dimorphism and environment. In CJ Schofield \& C Ponce (eds), Proceedings of the Second International Workshop on Population Biology and Control of Triatominae, 
Tegucigalpa, Honduras, INDRE, Mexico City (in press).

Dujardin JP, Forgues G, Torres M, Martinez E, Cordoba C, Gianella A 1998a. Morphometrics of domestic Panstrongylus rufotuberculatus in Bolivia. Ann Trop Med Parasitol 92: 219-228.

Frias D, Dujardin JP 1996. Detección de variación genética a nivel poblacional a través de electroforesis de isoenzimas, p. 45-50. In CJ Schofield, JP Dujardin, J Jurberg (eds), Proceedings of the International Workshop on Population Biology and Control of Triatominae, Santo Domingo de los Colorados, Ecuador, INDRE, Mexico City.

Garcia AL, Carrasco HJ, Schofield CJ, Valente SA, Frame IA, Stothard R, Miles MA 1998. Random Amplification of Polymorphic DNA as a tool for taxonomic studies of Triatomine bugs (Hemiptera: Reduviidae). J Med Entomol 35: 38-45.

Garcia BA, Powell JR 1998. Phylogeny of species of Triatoma (Hemiptera: Reduviidae) based on mitochondrial DNA sequences. J Med Entomol 35: 232238.

Garcia BA, Canale DM, Blanco A 1995. Genetic structure of four species of Triatoma (Hemiptera: Reduviidae) from Argentina. J Med Entomol 32: 134-137.

Gorla DE, Schofield CJ, Dujardin JP 1997. Biosystematics of Old World triatominae. Acta Tropica 63: 127 140

Lyman DL, Monteiro FA, Escalante AE, Cordon-Rosales C, Wesson DM, Dujardin J-P, Beard CB 1999. Mitochondrial DNA sequence variation among triatomine vectors of Chagas disease. Am J Trop Med Hyg (in press).

Noireau F, Bosseno MF, Carrasco R, Telleria J, Vargas F, Camacho C, Yaksic N, Brenière F 1995. Sylvatic triatomines (Hemiptera: Reduviidae) in Bolivia: trends toward domesticity and possible infection with Trypanosoma cruzi (Kinetoplastida: Trypanosomatidae). J Med Entomol 32: 594-598.

Panzera F, Pérez R, Hornos S, Nicolini P 1999. Citogenética y evolución cromosómica en triatominos. In CJ Schofield \& C Ponce (eds), Proceedings of the Second International Workshop on Population Biology and Control of Triatominae,
Tegucigalpa, Honduras, INDRE, Mexico City (in press).

Rabinovich JE 1974. Demographic strategies in animal populations: a regression analysis, p. 19-40. In FB Golloy \& E Medina (eds), Tropical Ecological Systems, Springer Verlag, New York.

Schofield CJ 1996. Biosystematics and adaptive trends in Triatominae - Overview, p. 45-50. In CJ Schofield, JP Dujardin \& J Jurberg (eds), Proceedings of the International Workshop on Population Biology and Control of Triatominae, Santo Domingo de los Colorados, Ecuador, INDRE, Mexico City.

Schofield CJ, Dolling WR 1993. Bedbugs and kissingbugs (bloodsucking Hemiptera), p. 483-516. In RPLane \& RWCrosskey (eds), Medical Insects and Arachnids, Chapman \& Hall, London, UK.

Schofield CJ, Lehane MJ McEwan P, Catalá SS, Gorla DE 1992. Dispersive flight by Triatoma infestans under natural climatic conditions in Argentina. Med Vet Entomol 6: 51-56.

Schofield CJ, Apt W, Sagua H, Panzera F, Dujardin JP 1998. Alary polymorphism in Triatoma spinolai and its possible relationship with demographic strategy. Med Vet Entomol 12: 30-38.

Soares RPP 1997. Aspectos Biológicos, Bioquímicos e Morfológicos Relacionados à Atividade de Vôo das Principais Espécies Vetoras da Doença de Chagas no Brasil, Thesis, UFMG, Belo Horizonte, 94 pp.

Stothard JR, Yamamoto Y, Cherchi A, Garcia AL, Valente SAS, Schofield CJ, Miles MA 1998. A preliminary survey of mitochondrial sequence variation in Triatominae (Hemiptera: Reduviidae) using polymerase chain reaction-based single strand conformational polymorphism (SSCP) analysis and direct sequencing. Bull Entomol Res 88: 553-560.

Taneja J, Guerin PM 1997. Ammonia attracts the haematophagous bug Triatoma infestans: behavioural and neurophysiological data on nymphs. J Compar Physiol A, 181: 21-34.

Valente VC, Valente SAS, Noireau F, Carrasco HJ, Miles MA 1998. Chagas disease in the Amazon Basin: Association of Panstrongylus geniculatus (Hemiptera: Reduviidae) with domestic pigs. $\mathrm{J} \mathrm{Med}$ Entomol 35: 99-103. 